\title{
Ethnologies
}

\section{Anthropology Through a Double Lens. Public and Personal Worlds in Human Theory. By Daniel Touro Linger. (Philadelphia: University of Pennsylvania Press, 2005. Pp. 195, reference notes, index, ISBN 0-8122-3857-5)}

\section{Marie Croll}

Volume 32, numéro 1, 2010

Jouer

Play

URI : https://id.erudit.org/iderudit/045221ar

DOI : https://doi.org/10.7202/045221ar

Aller au sommaire du numéro

Éditeur(s)

Association Canadienne d'Ethnologie et de Folklore

ISSN

1481-5974 (imprimé)

1708-0401 (numérique)

Découvrir la revue

Citer ce compte rendu

Croll, M. (2010). Compte rendu de [Anthropology Through a Double Lens. Public and Personal Worlds in Human Theory. By Daniel Touro Linger. (Philadelphia: University of Pennsylvania Press, 2005. Pp. 195, reference notes, index, ISBN 0-8122-3857-5)]. Ethnologies, 32(1), 220-223. https://doi.org/10.7202/045221ar d'utilisation que vous pouvez consulter en ligne. 


\section{References}

Kaldellis, Anthony. 2009 [2007]. "Hellenism in Byzantium: The Transformations of Greek Identity and the Reception of the Classical Tradition.” In Susan E. Alcock, Jas Elsner and Simon Goldhill, eds., Greek Culture in the Roman World. New York: Cambridge University Press.

Tamis, Anastasios Myrodis. 2005. The Greeks in Australia. Melbourne: Cambridge University Press.

Richard Barrett Indiana University

Anthropology Through a Double Lens. Public and Personal Worlds In Human Theory. By Daniel Touro Linger. (Philadelphia: University of Pennsylvania Press, 2005. Pp. 195, reference notes, index, ISBN 0-8122-38575)

Anthropologist Daniel Touro Linger begins his book with the observation that anthropology's current focus on cultural analysis is relegating experienced lives to the margins of scrutiny. The "double lens" of his title refers to the necessity of realigning micro individual with macro inquiry. This challenge to anthropology's predominant way of perceiving experience is overdue, as theoretical trends continue to dominate much of the research. Linger takes direct aim at the overwhelming use of abstractions inherent in the currently prevailing culturalist critique.

In order to frame his analysis of the missing person in present day anthropology, Linger returns us to the chicken and egg dilemma in Durkheim's classical sociology: does the individual control the social or does the social control the individual? He repeatedly refers back to Durkheim's distinction between the two polarities in exploring how it is that the personal experience commands far less attention than the collective one in current anthropological study. It strikes me, however, as perplexing that Linger should establish this argument on a generalization that he describes as "standard social science." As a sociologist I can confirm that not all sociology has been mired in this separation between the individual and social. From its inception sociology has offered diverse theories about "the individual". Perhaps then Linger's perspective says more about anthropology than the "social 
sciences," for which he professes to speak. Linger makes use of Durkheim, as his straw man, but he does not repay Durkheim in kind by imparting the complexity of this sociologist's work on the individual.

Linger's major site of analysis is how personal and public experiences combine to create areas of meaning. While this line of inquiry may be novel for anthropology, it is not for sociology as, for example, Dorothy Smith's work amply demonstrates. Linger consistently holds up examples of sociology that haven't explored this quarter, rather than those that have. These analytical incongruities represent just a few of the ways that this otherwise important work strays from the mark.

Linger has organized his book into three sections: "Meanings", "Politics", and "Identities". Each of these parts positions ethnographic work alongside theory in order to illuminate and vitalize the space between the individual and the social. In Part one, "Meanings", Linger asserts that meaning-making occurs in the crosscurrents between personal and social worlds. In order to tap into the immediacies of this zone of experience, anthropologists, according to Linger, must scrutinize the ways that individuals interact with the social form. Accordingly, the first chapter seeks to establish an inside-out perspective for anthropology, in particular from the perspective of psychological anthropology. In this section Linger also expands this theoretical standpoint towards a more communicative and interactive approach. He promotes a micro-level reflective consciousness, all the while countering other cultural and interpretative approaches. He maintains, for example, that discourse overwrites the individual whereas communication engrosses both the social and the intra-psychic.

The ethnologies developed by Linger to support and substantiate his case are vibrantly sculpted and engrossing. The first one begins with a query about the anthropological approach that "equates public representations with subjectivities" (50). This ethnography seeks to demonstrate how the identities of the Japanese Brazilians, who Linger has studied in Japan, were struggling to maintain their Japanese identities and ethnicity in the face of public and historic representations of Brazilian nationhood. Through his "spiders, not flies" analogy adapted from Geertz, Linger conveys to his reader the notion that people, not culture, weave the symbolic complexities and meanings in which we are enmeshed, and thus they evade being interpreted merely as text. Unfortunately, however, this insight is not what his ethnology 
demonstrates in an "intra-psychic" sense (37). To do so would require much closer analysis than Linger has undertaken. The content dealing with his subjects does not contain sufficient first person, intra-personal content, and nor is it comprehensive enough to expose the "range of actual thick, personal subjectivities" (15) that he sets out to unravel.

Part two, "Politics," explores through theory and person centered research, the political implications of power upon commonsense and reflective consciousness. Here the author investigates what it is that makes some social accounts rather than others so persuasive. Linger utilizes Gramsci to underscore his fascinating fieldwork undertaken in the mid 1980's Brazil, that scrutinizes abuse of power at many levels, localized political riots, and societies in the grips of profound change. While this fieldwork steps closer than his other studies to personal experience, once again Linger does not focus his lens closely enough to reveal the immediacies of the human lives that he says offers anthropology such a needed cultural perspective.

"Identities", the third and final section, maintains that identities cannot, and indeed must not, be reduced only to their social representations. Linger broadly questions whether anthropologists have been defensible in constructing their scholarly accounts of culturally defined groups, such as Japanese or Brazilian, which, he admits, both he and his ethnographic subjects also do. He wonders what such constructions achieve. His research aim, therefore, is to contribute to a new wave in anthropology, one that accentuates the personal and the experienced and seeks, in contrast, to avoid camouflaging experience through categorization and discourse, convergences, and variation in cultural identity. Linger's ethnographic content explores, though rather generally, the significance of personal identity and location for two Brazilians living in Japan, and in so doing he locates individual choice in identity construction.

By way of the very different ethnographies Linger uses in Anthropology Through a Double Lens, he is perhaps attempting to demonstrate the axiom that processes of meaning-making are varied and idiosyncratic. This is certainly a perspective and approach that warrants amplification. However, the ethnographic work employed by Linger for this purpose does not support the theoretical component of this study. The relationship between his ethnography and theory requires more careful delineation and the ethnographies need to move nearer 
to the individuals at their centre. Linger sets out to characterize personal experience within anthropology's predominantly theoretical and macro treatment and to bridge the two. Ultimately though, he does this in theory but not in practice. This being said, his study is still well worth reading. Linger confronts the existing drawbacks of anthropological research and teaching in evaluating the personal experience only through theoretical representations. He wades through analytical lexicons and successfully locates suitable language for describing experience without dehumanizing the person at anthropology's centre. Finally, Linger has directed much needed attention towards the relations between macro structures and subjectivities that are innermost for building theories of the individual.

\author{
Marie Croll \\ Memorial University \\ Cormer Brook, Newfoundland EF Labrador
}

The Arablan Nights Reader. By Ulrich Marzolph, ed., (Detroit, Wayne State University Press, 2006. Pp v-373, table of content, introduction, notes, work cited, index, ISBN 0-8143-3259-5)

The work of fiction Alf Laila wa-Laila or the Arabian Nights, as known in popular culture, was introduced to the West in the XVIIIth century. The Arabian Nights Reader is part of larger series in fairy-tale studies. Ulrich Marzolph, the editor, is one of the world's foremost scholars of Near Eastern narrative culture. His "Arabian Nights Reader" provides 16 articles, from both Eastern and Western scholars, in English language, and covers a research period of about 55 years (1942-1997). It aims at introducing non-specialists to relevant scholarly ideas and problems surrounding the Nights, as many scholars like to call them. However, this book, in spite of the intentions of its editor, assumes the reader is familiar with the topic and I would suggest that some preliminary research on the Arabian Nights would be advantageous.

The first part of the book is constituted by a single article, examining the researchers' reception of the Arabian Nights from the $19^{\text {th }}$ century onward, as well as the classification of genre, origins, and foreign influences. The author, Muhsin Jassim Ali, lists and criticized some of the greatest scholarly work done about the Nights that have cast the foundations for their study. 